\title{
Structures of P-type Transporting ATPases and Chromosomal Locations of Their Genes
}

\author{
Masatomo Maeda ${ }^{1, *}$, Kunihiko Hamano ${ }^{1}$, Yuko Hirano ${ }^{1}$, Mikio Suzuki ${ }^{2}$, Ei-ichi Takahashi², \\ Tomoyuki Terada ${ }^{1}$, Masamitsu Futai ${ }^{3}$, and Ryuichiro Sato ${ }^{1}$ \\ ${ }^{1}$ Laboratory of Biochemistry and Molecular Biology, Graduate School of Pharmaceutical Sciences, Osaka Uni- \\ versity, Suita, Osaka 565-0871, Japan, ${ }^{2}$ Gene Institute, Otsuka Pharmaceutical Company, Tokushima 771- \\ 0130, Japan, and ${ }^{3}$ Department of Biological Sciences, The Institute of Scientific and Industrial Research, Osaka \\ University, Ibaraki, Osaka 567-0047, Japan
}

Key words: channel/flippase/gene/ion transport/Mat-8/membrane recycling/P-type ATPase/sorting/transporting ATPase

\begin{abstract}
P-type ATPases ( $\mathbf{E}_{1} \mathbf{E}_{2}$-ATPases) are primary active transporters which form phospho-intermediates during their catalytic cycle. They are classified into P1 to P4 based on the primary structure and potential transmembrane segments. Although the classic P-type ATPases are cation transporters, two new members have recently been found; one is a flippase catalyzing the flip-flop movement of aminophospholipids, but the substrate and function of the other one remain unknown. It would be interesting to determine whether the cations and aminophospholipids are transported by similar or different mechanisms. P-type ATPases are believed to have been derived from a common ancestor, and their genes are found to be distributed in various chromosomal loci. However, gene duplication events can be traced from the tandem arrangement of genes and their linkage map. $\mathrm{Na}^{+} / \mathrm{K}^{+}$- and $\mathrm{H}^{+} / \mathrm{K}^{+}$-ATPases have not only closely related $\alpha$ subunits but also similar $\beta$ subunits. Renal $\mathrm{Na}^{+} / \mathrm{K}^{+}$-ATPase has an additional subunit $\gamma$. Similar small polypeptides (phospholemman, Mat-8 and CHIF), which induce $\mathrm{Cl}^{-}$and $\mathrm{K}^{+}$currents, have been found. The idea of their functional and structural coupling with P-type ATPases, especially with $\mathbf{H}^{+} / \mathrm{K}^{+}$-ATPase, is intriguing. Each P-type ATPase must have specific domains or sequences for its intracellular trafficking (sorting, retention and recycling). Identification of such regions and studies on the molecules playing role in their recognition may facilitate the unveiling of various cellular processes regulated by P-type ATPases.
\end{abstract}

\section{Prologue}

It is now widely accepted that the hydrolysis of ATP is coupled to the transport of varieties of inorganic and organic ions across the various membranes surrounding cell and cytoplasmic organelle compartments. The transporting ATPases (or pump ATPases) play essential roles in this process. These ATPases are classified into four group: P-type, F-type and V-type ATPases (1), and ABC-transporters (2). Information on the primary structures of these ATPases and the chromosomal locations of their genes is accumulating with the progress of the genome projects and the identification of the genes responsible for various human genetic

\footnotetext{
* To whom correspondence should be addressed.

Tel: +81-6-6879-8185, Fax: +81-6-6875-8189

Abbreviations used: FISH, fluorescence in situ hybridization; PCR, polymerase chain reaction; PMCA, plasma membrane $\mathrm{Ca}^{2+}$ ATPase; RACE, rapid amplification of cDNA ends; SCAMP, secretory carrier membrane protein; SERCA, sarco/endoplasmic reticulum $\mathrm{Ca}^{2+}$-ATPase; SNAP25, synaptosome-associated protein; VAMP, vesicle-associated membrane protein.
}

disorders (3). In this review, we focus on the P-type ATPases, which are believed to be derived from a common ancestral gene (4). Well-known P-type ATPase members such as $\mathrm{Na}^{+} / \mathrm{K}^{+}$-ATPase and $\mathrm{Ca}^{2+}$-ATPase play critical roles in regulating the intracellular ionic balance and driving physiological or biological processes (1).

P-type ATPases have the unique property of the formation of a high-energy phosphate-bond with the carboxyl moiety of a conserved aspartic acid residue. The term of "P-type" is derived from this phospho-intermediate, whose bond energy is utilized to drive cation movement through the membrane domain of the ATPase (1). P-type ATPase is a primary active transporter previously called $\mathrm{E}_{1} \mathrm{E}_{2}$-ATPase, since two conformational states $\left(\mathrm{E}_{1}\right.$ and $\left.\mathrm{E}_{2}\right)$ were indicated by kinetic studies (4). However, novel members whose substrates are aminophospholipids instead of cations have been found $(5,6)$. We will discuss the structural features of P-type ATPases, which are classified into three (7) or four (5) groups, the chromosomal locations of 
their genes, and then small single transmembrane polypeptides.

\section{Structural features of P-type ATPases}

Each member of the P-type ATPase family transports specific cations coupled with ATP hydrolysis and the formation of a high-energy phospho-intermediate through the DKTG sequence. Although the molecular weights of P-type ATPases are diverse (70-200 k), they have conserved motifs, such as [TGE(S/A)] in the conformationally flexible loop, [DKTG(S/T)] in the phosphorylation domain, (TGDN) in the ATP-binding domain, and (MXGDGXNDXP) in the junction between the ATP-binding domain and the transmembrane segment (7). Recently, P-type ATPases were classified into P1 to P3 (Fig. 1) based on the type of transported cations and the putative transmembrane domains (7).

The P1-ATPases involved in the transport of heavy metals $\left(\mathrm{Cd}^{2+}, \mathrm{Cu}^{2+}\right.$ and $\left.\mathrm{Hg}^{2+}\right)$ have only two transmembrane segments following the ATP-binding region, whereas P2-ATPases have six (M5-M10). P2ATPases have four transmembrane segments (M1-M4) preceding the ATP-binding region. However, two hydrophobic regions, which are potentially transmembrane, are further inserted prior to the TGE(S/A) sequence in P1-ATPases. P1-ATPases are also unique in that they have metal binding motifs (one to six of GMXCXXC or MXXMDHSXM sequences) in their amino-terminal regions, and have a transmembrane $\mathrm{CP}(\mathrm{C} / \mathrm{H})$ sequence and a $\mathrm{HP}(\mathrm{L} / \mathrm{V})$ sequence, each of which precedes and follows a phosphorylation site $(5,8-12)$. It would be interesting to know how these motifs and sequences participate in metal transport. Although P1-ATPases generally transport heavy metals from the cytoplasm to the outside, there is a bacterial enzyme which catalyses the uptake of $\mathrm{Cu}^{2+}$ from outside (9). P1-ATPases are also named CPx-type ATPases (10).

P2-ATPases (non-heavy-metal-transporting P-type ATPases) have four additional transmembrane segments (M7-M10) compared with P1-ATPases. P2ATPases are classified into two subgroups. The $\mathrm{Na}^{+} /$ $\mathrm{K}^{+}$- and $\mathrm{H}^{+} / \mathrm{K}^{+}$-ATPase subgroups have a catalytic $\alpha$ subunit and a glycosylated $\beta$ subunit. They exchange intracellular $\mathrm{Na}^{+}$or $\mathrm{H}^{+}$with extracellular $\mathrm{K}^{+}$. Four and three distinct $\mathrm{Na}^{+} / \mathrm{K}^{+}$- and $\mathrm{H}^{+} / \mathrm{K}^{+}$-ATPase $\alpha$ subunits, respectively, have been reported in mammals (Table I and the following). From recent studies, it was established that $\mathrm{H}^{+} / \mathrm{K}^{+}$-ATPase $\alpha$ isoforms are expressed tissue-specifically in the stomach $(\alpha 1)$ (13), colon and kidney $(\alpha 2)(14,15)$, and skin, kidney and brain, but not in the colon (ATP1AL1 $=\alpha 4)(15,16)$. The mRNAs for two splicing isoforms of $\mathrm{H}^{+} / \mathrm{K}^{+}$ATPase $\alpha 2$ increase coordinately in the kidney in response to chronic $\mathrm{K}^{+}$deprivation $(14,15) . \alpha 2$ is assem-

\section{P1-ATPase}

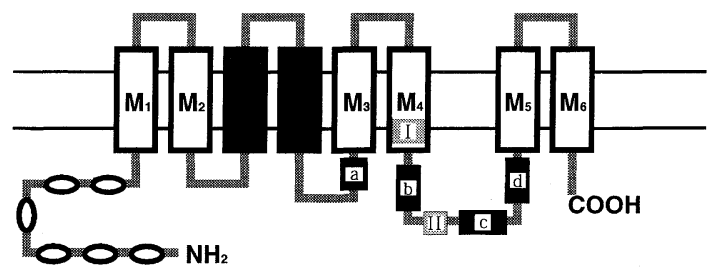

\section{P2-ATPase}

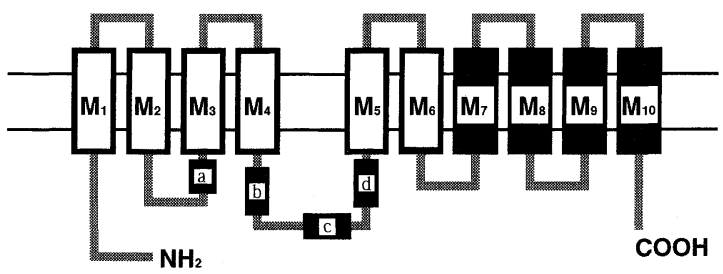

\section{P3-ATPase}

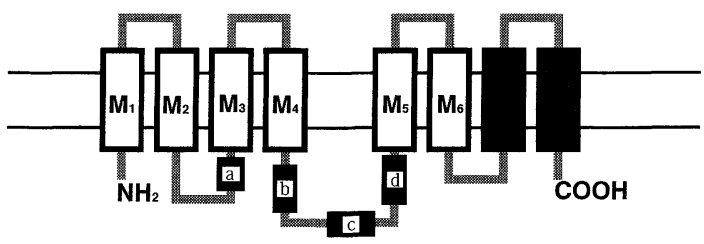

Fig. 1. Model of the transmembrane orientation of P-type ATPases. The transmembrane orientation of P1, P2 and P3-ATPases is shown (modified from ref 7). $\mathrm{M}_{1}-\mathrm{M}_{10}$ indicate transmembrane segments. Unique transmembrane segments for each group are indicated by closed boxes. However, the authors of Ref. 10 reported that the 1st and 2nd transmembrane segments of P1-ATPase are unique. Thus, the roles of these unique segments should be determined carefully in future studies. The positions of conserved amino acid sequences among P-type ATPases are schematically shown by small closed boxes with lower case letters [a, TGE(S/A); b, DKTG(S/T); c, TGDN; d, MXGDGXNDXP]. Characteristic sequences of P1-ATPase are shown by open boxes [I, CP(C/H); II, HP(L/V)]. The ovals are metal binding motifs located in the amino-terminal region of P1-ATPase. P4-ATPase has four or six transmembrane segments downstream of the phosphorylation site (small closed box " $b$ "), and the extracellular segment between M1 and M2 is extremely long (100-200 amino acid residues) (5). 
Table I. Chromosomal locations of P-type ATPase genes.

\begin{tabular}{|c|c|c|c|c|c|c|}
\hline ATPase & Subunit & Gene & Human & Mouse & Comments & Ref. \\
\hline \multirow[t]{9}{*}{$\mathrm{Na}^{+} / \mathrm{K}^{+}$} & $\alpha 1(\alpha \mathrm{A})$ & ATP1A1 & $1 \mathrm{p} 11-13$ & 3 & ubiquitous & (26)-(36) \\
\hline & $\alpha 2(\alpha \mathrm{B})$ & ATP1A2 & 1 cen-q32 & 1 & neural, muscle & \\
\hline & $\alpha 3$ & ATP1A3 & $19 q 13.2$ & 7 & neural & \\
\hline & $\alpha \mathrm{D}$ & ATP1AL1 & $13 q 12-14$ & & $\begin{array}{l}\text { brain, kidney, skin } \\
\mathrm{H}^{+} / \mathrm{K}^{+} \text {-ATPase }(\alpha 4)\end{array}$ & \\
\hline & $\alpha \mathrm{C}$ & ATP1AL2 & $1 \mathrm{q}_{\text {(next to } \alpha 2)}$ & & testis & \\
\hline & $\beta 1$ & ATP1B1 & $1 \mathrm{q}$ & 1 & & $(27),(29)$ \\
\hline & $\beta 2$ & ATP1B2 & & 11 & & $(30),(36)$ \\
\hline & $\beta 3$ & ATP1B3 & & 7 & & \\
\hline & $\beta 1^{*}$ & ATP1BL1 & 4 & & pseudogene & \\
\hline \multirow[t]{2}{*}{$\mathrm{H}^{+} / \mathrm{K}^{+}$} & $\alpha(\alpha 1)$ & ATP4A & $19 \mathrm{q} 13.11$ & 7 & & (34), (37) \\
\hline & $\beta$ & ATP4B & $13 q 34$ & 8 & & \\
\hline \multirow[t]{2}{*}{$\mathrm{Cu}^{2+}$} & & ATP7A & $\mathrm{Xq13.3}$ & $\mathrm{x}$ & Menkes disease & (3), (37)-(40) \\
\hline & & ATP7B & $13 q 14.3$ & 8 & Wilson's disease & \\
\hline \multirow[t]{3}{*}{$\begin{array}{l}\mathrm{Ca}^{2+} \\
\text { (sarco/endo-plasmic } \\
\text { reticulum) }\end{array}$} & & $\begin{array}{l}\text { ATP2A1 } \\
\text { (SERCA1) }\end{array}$ & $16 \mathrm{p} 12.1-12.2$ & 7 & $\begin{array}{l}\text { Brody disease } \\
\text { fast-twitch [adult (1a), } \\
\text { neonatal (1b)] }\end{array}$ & $(41)-(44)$ \\
\hline & & $\begin{array}{c}\text { ATP2A2 } \\
\text { (SERCA2) }\end{array}$ & $12 \mathrm{q} 23-24.1$ & & $\begin{array}{l}\text { cardiac/slow-twitch ( } 2 a) \text {, } \\
\text { smooth/non-muscle (2b) }\end{array}$ & \\
\hline & & $\begin{array}{c}\text { ATP2A3 } \\
\text { (SERCA3) }\end{array}$ & $17 \mathrm{p} 13.3$ & & non-muscle cells & \\
\hline \multirow[t]{4}{*}{$\begin{array}{l}\mathrm{Ca}^{2+} \\
\text { (plasma membrane) }\end{array}$} & & $\begin{array}{c}\text { ATP2B1 } \\
\text { (PMCA1) }\end{array}$ & $12 q 21-23$ & & ubiquitous & $(45)-(47)$ \\
\hline & & $\begin{array}{c}\text { ATP2B2 } \\
\text { (PMCA2) }\end{array}$ & $3 \mathrm{p} 25-26$ & & neuronal tissues & \\
\hline & & $\begin{array}{l}\text { ATP2B3 } \\
\text { (PMCA3) }\end{array}$ & $\mathrm{Xq} 28$ & & neuronal tissues & \\
\hline & & $\begin{array}{c}\text { ATP2B4 } \\
\text { (PMCA4) }\end{array}$ & $1 \mathrm{q} 25-32$ & & ubiquitous & \\
\hline
\end{tabular}

bled with $\mathrm{Na}^{+} / \mathrm{K}^{+}$-ATPase $\beta 1$ in the renal medulla and distal colon (17). A structurally different $\mathrm{H}^{+} / \mathrm{K}^{+}$ATPase $\alpha$ has been reported in the toad bladder (18). Members of the other P2-ATPase subgroup transport divalent $\left(\mathrm{Ca}^{2+}\right.$ or $\left.\mathrm{Mg}^{2+}\right)$ or monovalent $\left(\mathrm{Na}^{+}\right.$or $\left.\mathrm{H}^{+}\right)$ cations from the cytoplasm to the extracellular compartment. The plasma membrane (calmodulin-activated PMCA1, 2, 3 and 4) and sarco-endoplasmic reticulum (thapsigargin-sensitive SERCA1, 2 and 3) $\mathrm{Ca}^{2+}$ ATPases have not only isoforms but also splicing variants derived from a single gene $(19,20)$. The residues important for cation binding and transport by SERCA1 have been carefully studied and identified to be $\mathrm{Glu}^{309}$ in M4, Glu ${ }^{771}$ in M5, Asn ${ }^{796}, \mathrm{Thr}^{799}$ and $\mathrm{Asp}^{800}$ in M6, and Glu ${ }^{908}$ in M8 (20).

KdpB-ATPase, which is a part of a complex involved in $\mathrm{K}^{+}$uptake by Escherichia coli (21), is the only member of the P3-ATPase family. The carboxyterminal region of $\mathrm{KdpB}$ is short, as indicated by the reduced number of transmembrane segments compared with P2-ATPases. The amino-terminal hydrophilic region of P2-ATPases is suggested to be important for intramolecular interactions which could be essential for the conformational transition associated with cation efflux (7). However, this region of $\mathrm{KdpB}$ is also truncated.

\section{Expansion of P2-type $\mathrm{Ca}^{2+}$-ATPases}

Phylogenetic analysis suggests that there are two further groups of $\mathrm{Ca}^{2+}$-ATPases in addition to PMCA and SERCA (22). A third group [yeast Golgi PMR1 (plasma membrane $\mathrm{H}^{+}$-ATPase related) (5) and rat SPCA (secretory pathway $\mathrm{Ca}^{2+}$-ATPase) (23)] comprises the secretory pathway $\mathrm{Ca}^{2+}$-ATPases, which may represent the most ancient and widespread class of $\mathrm{Ca}^{2+}$ ATPases despite its being the least recognized. Golgi calcium, which seems to be important in the exocytic or secretory pathway, is stored by this $\mathrm{Ca}^{2+}$-ATPase. A fourth group found only in lower eukaryotes and chloroplasts exhibits significant similarities to PMCA, al- 
though it lacks a calmodulin-binding regulatory domain (22). The members are all located in intracellular acidic compartments such as vacuoles, suggesting their roles in the detoxification of high concentrations of $\mathrm{Ca}^{2+}$.

\section{Finding of novel P-type ATPases}

The above P-ATPases are all cation transporters. However, flippase (aminophospholipid translocase) found in bovine chromaffin granules (ATPase II) surprisingly belongs to the P2-ATPase family (6). Flippase catalyses the flip-flop movement of aminophospholipids such as phosphatidylserine and phosphatidylethanolamine between the inner and outer leaflets of a phospholpid bilayer coupled with ATP hydrolysis $(24,25)$. Similar ATPases are Drs2 (yeast), pfATPase 2 (Plasmodium falciparum), and the Caenorhabditis elegans ATPase on the CELT24H7.5 locus. The hydrophilic residues, important for cation binding and transport determined for SERCA1, are difficult to assign in the transmembrane regions (M4 and M6) of flippase $(5,6)$, suggesting that the transport mechanisms for cations and phospholipids could be different. Thus, it would be of interest to examine the mechanism underlying phospholipid flip-flop by P2-ATPases.

A total of 16 open reading frames encoding P-type ATPases have been identified in the yeast genome (5). Two members whose substrates are unknown are classified as P4-ATPases, and are homologous to ATPase I from $P$. falciparum and the $C$. elegans ATPase on the CEWO8D2 (5). P4-ATPases have an unusually long extra-membrane segment of 100-200 residues between transmembrane segments $\mathrm{M} 1$ and $\mathrm{M} 2$. The rest of the ATPases are P1-ATPases (2 members) and P2ATPases (12 members). P2-ATPases could be transporters for either $\mathrm{H}^{+}$( 2 members), $\mathrm{Ca}^{2+}$ ( 2 members), $\mathrm{Na}^{+}$(3 members), or possibly aminophospholipids (5 members including Drs2). Why the yeast has so many flippases and how these proteins participate in physiological processes such as vesicular sorting and membrane rearrangement are unknown.

\section{Chromosomal location of P-type ATPase genes}

It is interesting to consider how divergent P-type ATPase genes are dispersed from the view-point of chromosomal evolution and whether their evolution can be traced by comparing their locations on chromosomes. We compiled the gene mapping data for human and mouse P-type ATPases in Table $1(3,26-47)$. As for human $\mathrm{Na}^{+} / \mathrm{K}^{+}$-ATPase, four genes $(\alpha \mathrm{A}, \alpha \mathrm{B}, \alpha \mathrm{C}$ and $\alpha \mathrm{D}$ ) were identified in an early study (26). However, it is now believed that $\alpha \mathrm{D}(=\mathrm{ATP} 1 \mathrm{AL} 1)$ encodes $\mathrm{H}^{+} / \mathrm{K}^{+}$ATPase (16). Two $\mathrm{Na}^{+} / \mathrm{K}^{+}$-ATPase genes $[\alpha \mathrm{B}(=\alpha 2$, ATP1A2) and $\alpha \mathrm{C}$ (=ATP1AL2)] are located in tandem, suggesting that a gene duplication event could have occurred. Furthermore, closely related linkage groups which carry genes for the immunoglobulin superfamily members (BCM1, CD2 and LFA3) and ATPases (ATP1A2 and ATP1A1) were demonstrated by genetic linkage studies $(31,48)$; one linkage group possesses the BCM1 and ATP1A2 genes, which are conserved in mouse chromosome 1 and human chromosome 1q. Another group carries the genes for CD2 and LFA3, and the ATP1A1 gene on chromosomes 3 (mouse) and $1 \mathrm{p}$ (human). These findings suggest that a chromosome region including the precursors of the genes for the immunoglobulin superfamily members and ATPase duplicated and gave rise to the linkage groups now observed. The duplicated regions may have stayed together on chromosome 1 in man (with the insertion of a centromere), while they seem to have dispersed with the formation of chromosomes 1 and 3 in the mouse. Similarly, the rat ATP1A1 and ATP1A2 genes are located on chromosomes 2 and 13, respectively $(49,50)$.

A member of the $\mathrm{H}^{+} / \mathrm{K}^{+}$- and $\mathrm{Na}^{+} / \mathrm{K}^{+}$-ATPase subfamily has a small $\beta$ subunit in addition to the catalytic $\alpha$ subunit. The gene organization of the corresponding subunits of both ATPases is highly conserved $(51,52)$, suggesting that the $\alpha$ and $\beta$ subunit genes, respectively, evolved from the same ancestral gene. Actually, both genes encoding the gastric $\mathrm{H}^{+} / \mathrm{K}^{+}$-ATPase $\alpha$ and $\mathrm{Na}^{+}$ $/ \mathrm{K}^{+}$-ATPase $\alpha 3$ subunits (ATP4A and ATP1A3, respectively) are located on the human chromosome 19 and mouse chromosome 7 (34). In this study, we precisely mapped the human gastric $\mathrm{H}^{+} / \mathrm{K}^{+}$-ATPase $\alpha$ subunit gene to chromosome $19 \mathrm{q}_{13.11}$ (Fig. 2). The genes for the $\mathrm{Na}^{+} / \mathrm{K}^{+}$-ATPase $\beta 1$ and $\mathrm{H}^{+} / \mathrm{K}^{+}$-ATPase $\beta$ subunits (ATP1B1 and ATP4B, respectively) are associated with the $\alpha$ subunit genes (ATP1A2 and ATP1AL2, and ATP1AL1, respectively). Other P-type ATPase genes (for catalytic subunits) are also often distributed on the same chromosomes: gene pairs ATP1AL1 and ATP7B, ATP1A2 and ATP2B4, ATP2A2 and ATP2B1, and ATP7A and ATP2B3 are located on chromosomes 13q, 1q, 12q, and Xq, respectively.

\section{Small single transmembrane polypeptides and P-type ATPases}

The presence of a $\gamma$ subunit in addition to $\alpha$ and $\beta$ subunits has long been discussed for $\mathrm{Na}^{+} / \mathrm{K}^{+}$-ATPase (53). Recently, a polypeptide consisting of 58 amino acids was reported to be a potential $\gamma$ subunit for various vertebrate $\mathrm{Na}^{+} / \mathrm{K}^{+}$-ATPases (54-56). This polypeptide having a single transmembrane domain is colocalized with the $\alpha$ subunit in the basolateral membrane of renal epithelial cells (54), and is copurified with the $\alpha$ and $\beta$ subunits, and forms the cardiac glycoside binding site together with the $\alpha$ subunit $(54,55)$. The 


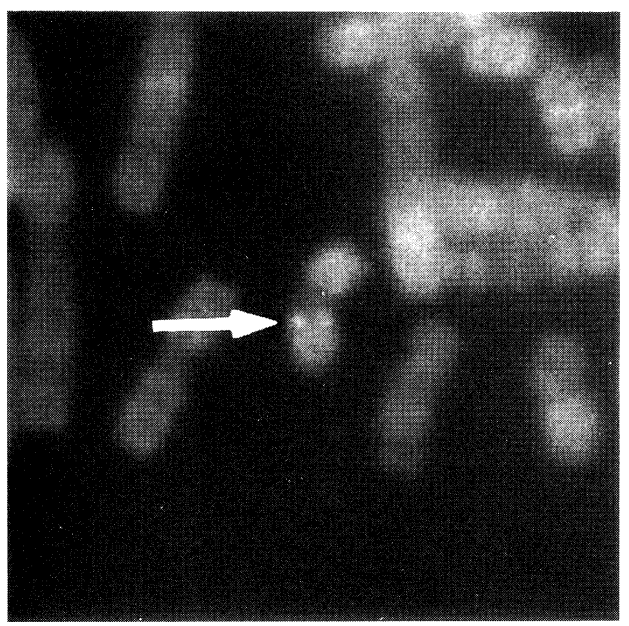

Fig. 2. Localization of the human gastric $\mathrm{H}^{+} / \mathrm{K}^{+}$-ATPase $\alpha$ subunit gene on R-banded metaphase chromosomes determined by FISH. From a phage clone (51), we prepared a DNA probe for mapping, which is based on FISH combined with replicated prometaphase Rbands $(74,75)$. To suppress repetitive sequences contained in the cosmid clones, we used 2-fold excess human Cot-1 DNA (76). Microphotography (Filter combination, Nikon B-2A) was performed with Provia 100 film (Fuji, ISO 100). We observed 100 typical R-banded chromosomes. The signals of the clone were localized to the p13.11 band of chromosome 19. No signal was detected on other chromosomes. Thus, the human $\mathrm{H}^{+} / \mathrm{K}^{+}$-ATPase $\alpha$ subunit gene was assigned to chromosome $19 \mathrm{q} 13.11$.

peptide stabilizes the $\mathrm{E}_{1}$ conformation of $\mathrm{Na}^{+} / \mathrm{K}^{+}$ATPase (57). Cardiac sarcoplasmic reticulum $\mathrm{Ca}^{2+}$ ATPase is inhibited by a small membrane protein composed of 52 amino acids, phospholamban (58). The phosphorylation of phospholamban by cAMP-dependent protein kinase and $\mathrm{Ca}^{2+} /$ calmodulin-dependent protein kinase reverses the inhibition. However, there is no sequence similarity between the $\mathrm{Na}^{+} / \mathrm{K}^{+}$-ATPase $\gamma$ subunit and phospholamban (54). Furthermore, the membrane topologies of these proteins are different: the carboxy- and amino-terminal regions of the $\gamma$ subunit and phospholamban, respectively, are postulated to be in the cytoplasm $(58,59)$.

Three polypeptides closely related to the $\gamma$ subunit are now known. The major sarcolemmal substrate for cAMP-dependent protein kinase and protein kinase $\mathrm{C}$ in the myocardium is phospholemman, a small transmembrane protein (59). A mature form (72 amino acid residues) is formed through the cleavage of 20 amino terminal residues. Mat- 8 (mammary tumor, $8 \mathrm{kDa}$ ) is a marker of a cell type preferentially transformed by $\mathrm{Neu}$ or Ras oncoproteins $(60,61)$. CHIF (channel-inducing factor) is induced in the colon by corticosteroids (62). The extracellular and transmembrane domains of phospholemman, Mat- 8 and CHIF are homologous to those of the $\gamma$ subunit of $\mathrm{Na}^{+} / \mathrm{K}^{+}$-ATPase (Fig. 3). Interestingly, phospholemman (63) and Mat-8 (61) induce a $\mathrm{Cl}^{-}$current while CHIF (62) induces a $\mathrm{K}^{+}$current, when expressed in Xenopus oocytes. Since it seems unlikely that they form membrane pores by themselves, they may function as modulators capable of activating endogenous oocyte channels. However, the roles of these small polypeptides in vivo remain unknown.

Although it has not been determined whether or not the $\gamma$ subunit of $\mathrm{Na}^{+} / \mathrm{K}^{+}$-ATPase exhibits similar activity, it is tempting to postulate that these small single transmembrane polypeptides are associated with cation

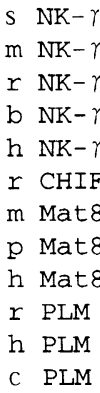

** $* * * \quad * * \quad * * * \quad * * \quad * \quad * * \quad * \quad * * * * * *$

ENEDPFYYDYETVRNGGLIFAA-LAFIVGLVIILSKRFRCGAKKKHRQIPEDGL MVAVQGTENPFEYDYETVRKGGLIFAG-LAFVVGLLIILSKRFRCGGGKKHRQVNEDEL MVAVQGTENPFEYDYETVRKGGLIFAG-LAFVVGLLILLSKRFRCGGSKKHRQVNEDEL MVAVQGTEDPFYYDYETVRNGGLIFAA-LAFIVGLVIILSKRFRCGAKRQHRQIPEDGL MAAAKGDVDPFYYDYETVRNGGLIFAG-LAFIVGLLILLSRRFRCGGNKKRRQINEDEP MEGITCAFLLVLAGLPVLEANGPVDKGSPFYYDWESLQLGGMIFGGLLC-IAGIAMALSGKCKCRRNH---TPSSLPEKVTPLITPGSAST MOEVVLSLLVLLAGLPTLDANDPENKNDPFYYDWYSLRVGGLICAGILCAL-GI IVLMSGKCKCKFRQKPSHRPGEGPPLITPGSAHNC MHEVALSVLILLAGLSALDANDPEDKNSPFYYDWHSLRVGGLICAGTPCAL-GIIILLSGKCKCKFSQKPSHRPGDAPPLITPGSAHDC MOKVTLGLLVFLAGFPVLDANDLEDKNSPFYYDWHSLQVGGLICAGVLCAM-GI I IVMSAKCKCKFGQKSGHHPGETPPLITPGSAQS M-APLHHILIVCVCLLSMASAEAPQEPDPFTYDYHTLRIGGLTIAGIL-FILGILIILSKRCRCKFNQQQRTGEPDEEEGTFRSSIRRLSTRRR M-APL HHILVFCVGLLTMAKAESPKEHDPFTYDYOSLQIGGLVIAGIL-FILGILIVLSRRCRCKFNQQQRTGEPDEEEGTFRSSIRRLSTRRR M-APLHHILVLCVGFLTTATAEAPQEHDPFTYDYQSLRIGGLIIAGIL-FILGILIVLSRRCRCKFNQQQRTGEPDEEEGTFRSSIRRLSTRRR

Fig. 3. Alignment of the amino acid sequences of $\mathrm{Na}^{+} / \mathrm{K}^{+}$-ATPase $\gamma$ subunits and related small proteins. The amino acid sequences of the $\mathrm{Na}^{+} / \mathrm{K}^{+}$-ATPase $\gamma$ subunits (NK- $\gamma$ ) [sheep, mouse, rat, bovine (54), and human (55)], phospholemman (PLM) [rat and human (77), and canine (59)], CHIF (62), and Mat-8 [mouse (60), human (61), and pig (this study)] are aligned [b, bovine; c, canine; h, human; m, mouse; p, pig; r, rat; $\mathrm{s}$, sheep]. The potential transmembrane domain was thick-underlined. Conserved residues are indicated by asterisks. The arrowhead indicates the cleavage site of the signal sequence of canine phospholemman. The amino acid sequence of pig Mat-8 was deduced in this study from cDNA, which was prepared from total RNA of pig gastric mucosa (78). The oligonucleotide mixture [ $3^{\prime}$-gg(gatc)aa(ag)at(ag)at(ag)ct(ag)at(ag)ct-5'] corresponding to the conserved PFYYDYE sequence was synthesized and used as the PCR-primer for 5'-RACE. The full-length cDNA was further amplified by PCR using the 5 -side primer (designed from the amplified sequence) and an oligo-dT ${ }_{14}$ primer. The nucleotide sequence has been submitted to the GenBank Data Bank with accession number AB015759. 
transport by P-type ATPases and modulate channel(s). In gastric parietal cells, the coupling of $\mathrm{Cl}^{-}$and $\mathrm{K}^{+}$ movements through channels with the antiport of $\mathrm{H}^{+}$ and $\mathrm{K}^{+}$by $\mathrm{H}^{+} / \mathrm{K}^{+}$-ATPase is essential for acid $(\mathrm{HCl})$ secretion $(64,65)$. Mouse Mat-8 is transcribed at high levels in the uterus, stomach and colon, while phospholemman is transcribed in the heart, skeletal muscle and liver (63). Here we have cloned a cDNA for Mat-8 from pig gastric mucosa by means of a homology cloning method with degenerate primers designed for conserved regions of the $\gamma$ subunit, phospholemman and Mat-8 (Fig. 3). Thus it would be interesting to determine whether or not such small single transmembrane polypeptides, especially Mat-8, function with the gastric $\mathrm{H}^{+} / \mathrm{K}^{+}$-ATPase to secrete gastric acid from parietal cells.

\section{Epilogue}

The aspect that should be pointed out lastly is the mechanisms which govern the distribution of various $\mathrm{P}$ type ATPases in specific organelles and membrane domains. Such localization is clearly important for regulation of the transport functions of the ATPases (66). Ptype ATPase genes have not only been distributed to different chromosomal loci but also potentially evolved by capturing the DNA sequences, which encode specific domains or amino acid sequences for sorting ATPases to different cellular locations. $\mathrm{Na}^{+} / \mathrm{K}^{+}$ATPase seems to interact with the intracellular sorting machinery and to be targeted to the basolateral surface, where the cytoskeleton can directly participate in retention of the $\mathrm{Na}^{+} / \mathrm{K}^{+}$-ATPase (66). Residues near the carboxy-terminal of the $\mathrm{Na}^{+}-\mathrm{K}^{+}$-ATPase $\alpha$-subunit are necessary for the formation of the $\alpha-\beta$ complex (67). In the $\mathrm{Na}^{+} / \mathrm{K}^{+}$- and gastric $\mathrm{H}^{+} / \mathrm{K}^{+}$. ATPases, the amino terminal regions of the $\alpha$ subunit are rich in lysine residues (68). The functional signifi cance of phosphorylation or dephosphorylation of Ser and Tyr residues in this region of $\mathrm{H}^{+} / \mathrm{K}^{+}$-ATPase for catalysis and/or sorting is not known (69), although removal of the Lys-rich sequence of $\mathrm{Na}^{+} / \mathrm{K}^{+}$-ATPase affected the conformational equilibrium which resulted in a change in the apparent affinity for $\mathrm{K}^{+}(70)$.

Tubulovesicles enriched in gastric $\mathrm{H}^{+} / \mathrm{K}^{+}$-ATPase fuse with the apical plasma membrane of parietal cells to form secretory canaliculi in response to secretagogues. This fusion event inserts the $\mathrm{H}^{+} / \mathrm{K}^{+}$-ATPase into the apical surface to secrete $\mathrm{HCl}$ into the lumen of the gastric gland (71). A sorting signal has been delimited to a sequence of eight amino acids present in the fourth predicted transmembrane domain of the $\alpha$ subunit, and apical delivery of the subunit may be determined by the ability of this sequence to be partitioned into glycosphingolipid-rich membrane patches (66). The cessation of acid secretion is associated with the re- trieval of the $\mathrm{H}^{+} / \mathrm{K}^{+}$-ATPase from the cell surface and the regeneration of tubulovesicles that are competent for another round of fusion (71). The gastric $\mathrm{H}^{+} / \mathrm{K}^{+}$ATPase, VAMP-2, Rab11, Rab25 and SCAMPs, but not syntaxin $1 \mathrm{~A} / 1 \mathrm{~B}$ or SNAP25, are present on the tubulovesicles, supporting the apical membrane recycling model of parietal cell secretion (72). The cytoplasmic tail of the $\mathrm{H}^{+} / \mathrm{K}^{+}$-ATPase $\beta$ subunit includes the sequence, FRQY, which is an internalization signal (YXRF or FRXY), and the ATPase no longer could return to the tubulovesicles when this signal was disrupted (73).

Each P-type ATPase member shows a high degree of structural similarity and commonly forms a phosphointermediate. The interesting points are the finding of aminophospholipid flippases as well as members of the P-type ATPase family with unknown functions. It must be determined in the near future whether or not the recognition of substrates (phospholipids and cations) and their transport occur through essentially the similar processes or complete different mechanisms. Examination of the functional and/or structural coupling between small membrane proteins and P-type ATPases as well as of the mechanisms of their intracellular trafficking is also important for understanding cellular physiological and biological processes regulated by P-type ATPases.

Acknowledgements. This research was supported in part by grants from the Ministry of Education, Science, Sports and Culture of Japan, the Mitsubishi Foundation, and the Naito Foundation.

\section{REFERENCES}

1. Pedersen, P.L. and Carafoli, E. 1987. Ion motive ATPases. I. Ubiquity, properties, and significance to cell function. Trends Biochem. Sci., 12: 146-150.

2. Hyde, S.C., Emsley, P., Hartshorn, M.J., Mimmack, M.M., Gileadi, U., Pearce, S.R., Gallagher, M.P., Gill, D.R., HubBaRD, R.E., and Higgins, C.F. 1990. Structural model of ATP-binding proteins associated with cystic fibrosis, multidrug resistance and bacterial transport. Nature, 346: 362-365.

3. TÜMER, Z. and HoRN, N. 1997. Menkes disease: recent advances and new aspects. J. Med. Genet., 34: 265-274.

4. JøRGENSEN, P.L. and ANDERSEN, J.P. 1988. Structural basis for E1-E2 conformational transitions in Na,K-pump and Capump proteins. J. Membrane Biol., 103: 95-120.

5. Catty, P., de Kerchove D'Exaerde, A., and Goffeau, A. 1997. The complete inventory of the yeast Saccharomyces cerevisiae P-type transport ATPases. FEBS Lett., 409: 325-332.

6. TaNG, X., Halleck, M.S., Schlegel, R.A., and Williamson, P. 1996. A subfamily of P-type ATPases with aminophospholipid transporting activity. Science, 272: 1495-1497.

7. Lutsenko, S. and Kaplan, J.H. 1995. Organization of P-type ATPases: significance of structural diversity. Biochemistry, 34: 15607-15613.

8. Silver, S., Nucifora, G., ChU, L., and Misra, T.K. 1989. Bacterial resistance ATPases: primary pumps for exporting tox- 
ic cations and anions. Trends Biochem. Sci., 14: 76-80.

9. Solioz, M., Odermatt, A., and Krapf, R. 1994. Copper pumping ATPases: common concepts in bacteria and man. FEBS Lett., 346: 44-47.

10. Solioz, M. and Vulpe, C. 1996. CPx-type ATPases: a class of P-type ATPases that pump heavy metals. Trends Biochem. Sci., 21: $237-241$.

11. Sambongi, Y., Wakabayashi, T., Yoshimizu, T., Oмote, H., OKA, T., and FUtAI, M. 1997. Caenohabditis elegans cDNA for a Menkes/Wilson disease gene homologous and its function in a yeast $C C C 2$ gene deletion mutant. J. Biochem., 121: 1169-1175.

12. Ima, M., Terada, K., Sambongi, Y., Wakabayashi, T., Miura, N., Koyama, K., Futai, M., and Sugiyama, T. 1998. Analysis of functional domains of Wilson disease protein (ATP7B) in Saccharomyces cerevisiae. FEBS Lett., 428: 281285.

13. Oshiman, K., Motojima, K., Mahmood, S., Shimada, A., Tamura, S., Maeda, M., and Futai, M. 1991. Control region and gastric specific transcription of the rat $\mathrm{H}^{+}, \mathrm{K}^{+}-$ ATPase $\alpha$ subunit gene. FEBS Lett., 281: 250-254.

14. Cougnon, M., Planelles, G., Crowson, M.S., Shull, G.E., Rossier, B.C., and JAISSER, F. 1996. The rat distal colon P-ATPase $\alpha$ subunit encodes a ouabain-sensitive $\mathrm{H}^{+}, \mathrm{K}^{+}-$ ATPase. J. Biol. Chem., 271: 7277-7280.

15. Kone, B.C. and Higham, S.C. 1998. A novel N-terminal splice variant of the rat $\mathrm{H}^{+}-\mathrm{K}^{+}$-ATPase $\alpha 2$ subunit: cloning, functional expression, and renal adaptive response to chronic hypokalemia. J. Biol. Chem., 273: 2543-2552.

16. Grishin, A.V., Bevensee, M.O., Modyanov, N.N., Rajendran, V., Boron, W.F., and Caplan, M.J. 1996. Functional expression of the cDNA encoded by the human ATP1AL1 gene. Am. J. Physiol., 271: F539-551.

17. Codina, J., Delmas-Mata, J.T., and DuBose, T.D. Jr. 1998. The $\alpha$-subunit of the colonic $\mathrm{H}^{+}, \mathrm{K}^{+}$-ATPase assembles with $\beta 1-\mathrm{Na}^{+}, \mathrm{K}^{+}$-ATPase in kidney and distal colon. J. Biol. Chem., 273: 7894-7899.

18. JAISSER, F., Horisberger, J.-D., GEering, K., and RosSier, B. 1993. Mechanisms of urinary $\mathrm{K}^{+}$and $\mathrm{H}^{+}$excretion: primary structure and functional expression of a novel H,K-ATPase. $J$. Cell Biol., 123: 1421-1429.

19. Carafoli, E. 1994. Biogenesis: plasma membrane calcium ATPase: 15 years of work on the purified enzyme. FASEB J., 8: 993-1002.

20. MacLennan, D.H., Rice, W.J., and Green, N.M. 1997. The mechanism of $\mathrm{Ca}^{2+}$ transport by sarco(endo)plasmic reticulum $\mathrm{Ca}^{2+}$-ATPases. J. Biol. Chem., 272: 28815-28818.

21. Hesse, J.E., WieczoreK, L., Altendorf, K., Reicin, A.S., Dorus, E., and Epstein, W. 1984. Sequence homology between two membrane transport ATPases, the Kdp-ATPase of Escherichia coli and the $\mathrm{Ca}^{2+}$-ATPase of sarcoplasmic reticulum. Proc. Natl. Acad. Sci. USA, 81: 4746-4750.

22. Sorin, A., Rosas, G., and RaO, R. 1997. PMR1, a $\mathrm{Ca}^{2+}$ ATPase in yeast Golgi, has properties distinct from Sarco/endoplasmic reticulum and plasma membrane calcium pumps. $J$. Biol. Chem., 272: 9895-9901.

23. Gunteski-Hamblin, A.-M., Clarke, D.M., and Shull, G.E. 1992. Molecular cloning and tissue distribution of alternatively spliced mRNAs encoding possible mammalian homologues of the yeast secretory pathway calcium pump. Biochemistry, 31: $7600-7608$.

24. Auland, M.E., Roufogalis, B.D., Devaux, P.E., and ZACHOWSKI, A. 1994. Reconstitution of ATP-dependent ami- nophospholipid translocation in proteoliposomes. Proc. Natl. Acad. Sci. USA, 91: 10938-10942.

25. ZaChowski, A., Henry, J.-P., and Devaux, P.F. 1989. Control of transmembrane lipid asymmetry in chromaffin granules by an ATP-dependent protein. Nature, 340: 75-76.

26. Shull, M.M. and Lingrel, J.B. 1987. Multiple genes encode the human $\mathrm{Na}^{+}, \mathrm{K}^{+}$-ATPase catalytic subunit. Proc. Natl. Acad. Sci. USA, 84: 4039-4043.

27. Kent, R.B., Fallows, D.A., Geissler, E., Glaser, T., Emanuel, J.R., Lalley, P.A., Levenson, R., and Housman, D.E. 1987. Genes encoding alpha and beta subunits of Na,KATPase are located on three different chromosomes in the mouse. Proc. Natl. Acad. Sci. USA, 84: 5369-5373.

28. Chehab, F.F., Kan, Y.W., LaW, M.L., HaRtz, J., KaO, F.T. and Blostein, R. 1987. Human placental $\mathrm{Na}^{+}, \mathrm{K}^{+}$-ATPase alpha subunit: cDNA cloning, tissue expression, DNA polymorphism, and chromosomal location. Proc. Natl. Acad. Sci. USA, 84: 7901-7905.

29. Yang-Feng, T.L., Schneider, J.W., Lindgren, V., Shull, M.M., BenZ, E.J.Jr., Lingrel, J.B., and FranCKe, U. 1988. Chromosomal localization of human $\mathrm{Na}^{+}, \mathrm{K}^{+}$-ATPase alphaand beta-subunit genes. Genomics, 2: 128-138.

30. Malo, D., Schurr, E., Levenson, R., and Gros, P. 1990. Assignment of Na,K-ATPase beta 2-subunit gene (Atpb-2) to mouse chromosome 11. Genomics, 6: 697-699.

31. Wong, Y.W., Williams, A.F., Kingsmore, S.F., and Seldin, M.F. 1990. Structure, expression, and genetic linkage of the mouse BCM1 (OX45 or Blast-1) antigen. Evidence for genetic duplication giving rise to the BCM1 region on mouse chromosome 1 and the CD2/LFA3 region on mouse chromosome 3. $J$. Exp. Med., 171: 2115-2130.

32. Cavanna, J.S., Greenfield, A.J., Johnson, K.J., Marks, A.R., NADAL-Ginard, B., and BRown, S.D. 1990. Establishment of the mouse chromosome 7 region with homology to the myotonic dystrophy region of human chromosome $19 \mathrm{q}$. Genomics, 7: 12-18.

33. Albritton, L.M., Bowcock, A.M., Eddy, R.L., Morton, C.C., Tseng, L., Farrer, L.A., Cavalli-Sforza, L.L., Shows, T.B., and Cunningham, J.M. 1992. The human cationic amino acid transporter (ATRC1): physical and genetic mapping to 13q12-q14. Genomics, 12: 430-434.

34. Malo, D., Gros, P., Bergmann, A., Trask, B., Mohrenweiser, H.W., Canfield, V.A., and Levenson, R. 1993. Genes encoding the H,K-ATPase alpha and N,KATPase alpha3 subunits are linked on mouse chromosome 7 and human chromosome 19. Mamm. Genome, 4: 644-649.

35. Shamraj, O.I. and Lingrel, J.B. 1994. A putative fourth $\mathrm{Na}^{+}, \mathrm{K}^{+}$-ATPase alpha-subunit gene is expressed in testis. Proc. Natl. Acad. Sci. USA, 91: 12952-12956.

36. Malik, N., CANField, V.A., Beckers, M.C., Gros, P., and LEVENSON, R. 1996. Identification of the mammalian Na,KATPase 3 subunit. J. Biol. Chem., 271: 22754-22758.

37. Reed, V., Williamson, P., Bull, P.C., Cox, D.W., and Boyd, Y. 1995. Mapping of the mouse homologue of the Wilson disease gene to mouse chromosome 8. Genomics, 28: 573-575.

38. Vulpe, C., Levinson, B., Whitney, S., Packman, S., and GITSCHIER, J. 1993. Isolation of a candidate gene for Menkes disease and evidence that it encodes a copper-transporting ATPase. Nature Genet., 3: 7-13.

39. Bull, P.C., Thomas, G.R., Rommens, J.M., Forbes, J.R., and Cox, D.W. 1993. The Wilson disease gene is a putative copper transporting P-type ATPase similar to the Menkes gene. $\mathrm{Na}$ ture Genet., 5: 327-337. 
40. Levinson, B., Vulpe, C., Elder, B., Martin, C., Verley, F., Packman, S., and Gitschier, J. 1994. The mottled gene is the mouse homologue of the Menkes disease gene. Nature Genet., 6: $369-373$.

41. Otsu, K., Fujil, J., Periasamy, M., Difilippantonia, M., UpPender, M., Ward, D.C., and Maclennan, D.H. 1993. Chromosomal mapping of five human cardiac and skeletal muscle sarcoplasmic reticulum protein genes. Genomics, 17: 507509.

42. Dode, L., Wuytack, F., Kools, P.F., Baba-Aissa, F., Raeymaekers, L., BRIK, F., VAN DE Ven, W.J., and Casteels, R. 1996. cDNA cloning, expression and chromosomal localization of the human sarco/endoplasmic reticulum $\mathrm{Ca}^{2+}$-ATPase 3 gene. Biochem. J., 318: 689-699.

43. Odermatt, A., Taschner, P.E., Khanna, V.K., Busch, H.F., Karpati, G., Jablecki, C.K., Breuning, M.H., and MacLennan, D.H. 1996. Mutations in the gene-encoding SERCA1, the first-twitch skeletal muscle sarcoplasmic reticulum $\mathrm{Ca}^{2+}$ ATPase. Nature Genet., 14: 191-194.

44. Schleef, M., Simon-Chazottes, D., Jengeling, A., Klocke, R., Jockusch, H., Yarden, Y., and Guenet, J. 1996. The gene encoding sarcoplasmic reticulum, and its elimination as a candidate gene for Brody disease. Mamm. Genome, 7: 788.

45. Olson, S., Wang, M.G., Carafoli, E., Strehler, E.E., and MCBRIDE, O.W. 1991. Localization of two genes encoding plasma membrane $\mathrm{Ca}^{2+}$-transporting ATPases to human chromosome 1q25-32 and 12q21-23. Genomics, 9: 629-641.

46. Wang, M.G., Yi, H., Hilfiker, H., Carafoli, E., Strehler, E.E., and McBriDE, O.W. 1994. Localization of two genes encoding plasma membrane $\mathrm{Ca}^{2+}$ ATPases isoform 2 (ATP2B2) and 3 (ATP2B3) to human chromosome $3 \mathrm{p} 26 \rightarrow \mathrm{p} 25$ and Xq28, respectively. Cytogenet. Cell Genet., 67: 41-45.

47. Stauffer, T.P., Guerini, D., and Carafoli, E. 1995. Tissue distribution of the four gene products of the plasma membrane $\mathrm{Ca}^{2+}$ pump: A study using specific antibodies. J. Biol. Chem., 270: 12184-12190.

48. Kingsmore, S.F., Souryal, C.A., Watson, M.L., Patel, D.D., and SeLdin, M.F. 1995. Physical and genetic linkage of the genes encoding Ly-9 and CD48 on mouse and human chromosomes 1. Immunogenetics, 42: 59-62.

49. Remmers, E.F., Goldmuntz, E.A., Zha, H., Mathern, P., Du, Y., Crofford, L.J., and Wilder, R.L. 1993. Linkage map of nine loci defined by polymorphic DNA markers assigned to rat chromosome 13. Genomics, 18: 277-282.

50. Zha, H., Wilder, R.L., Goldmuntz, E.A., CaSh, J.M., Crofford, L.J., Mathern, P., and Remmers, E.F. 1993. Linkage map of 10 polymorphic markers on rat chromosome 2. Cytogenet. Cell Genet., 63: 117-123.

51. Maeda, M., Oshiman, K., Tamura, S., and Futai, M. 1990. Human gastric $\left(\mathrm{H}^{+}+\mathrm{K}^{+}\right)$-ATPase gene: similarity to $\left(\mathrm{Na}^{+}+\right.$ $\mathrm{K}^{+}$)-ATPase genes in exon/intron organization but difference in control region. J. Biol. Chem., 265: 9027-9032.

52. Maeda, M., Oshiman, K., Tamura, S., Kaya, S., Mahmood, S., Reuben, M.A., Lasater, L.S., Sachs, G., and Futai, M. 1991. The rat $\mathrm{H}^{+} / \mathrm{K}^{+}$-ATPase $\beta$ subunit gene and recognition of its control region by gastric DNA binding protein. J. Biol. Chem., 266: 21584-21588.

53. Forbush, B.III., Kaplan, J.H., and Hoffman, J.F. 1978. Characterization of a new photoaffinity derivative of ouabain: labeling of the large polypeptide and of a proteolipid component of the Na,K-ATPase. Biochemistry, 17: 3667-3676.

54. Mercer, R.W., Biemesderfer, D., Bliss, D.P., Jr., Collins, J.H., and FoRBUSH, B.III. 1993. Molecular cloning and immu- nological characterization of the $\gamma$ polypeptide, a small protein associated with the Na,K-ATPase. J. Cell Biol., 121: 579-586.

55. Kim, J.W., Lee, Y., LeE, I.A., KAMG, H.B., ChOE, Y.K., and Chов, I.S. 1977. Cloning and expression of human cDNA encoding $\mathrm{Na}^{+}, \mathrm{K}^{+}$-ATPase $\gamma$-subunit. Biochim. Biophys. Acta, 1350: $133-135$.

56. Béguin, P., Wang, X., Firsov, D., Puoti, A., Claeys, D., HORISBERGER, J.-D., and GEERING, K. 1997. The $\gamma$ subunit is a specific component of the Na,K-ATPase and modulates its transport function. EMBO J., 16: 4250-4260.

57. Therien, A.G., GoldShleger, R., Karlish, S.J.D., and Blostein, R. 1997. Tissue-specific distribution and modulatory role of the $\gamma$ subunit of the Na,K-ATPase. J. Biol. Chem., 272: $32628-32634$.

58. Toyofuku, T., Kurzydlowski, K., TADA, M., and MacLennan, D.H. 1994. Amino acids Lys-Asp-Asp-Lys-Pro$\mathrm{Val}^{402}$ in the $\mathrm{Ca}^{2+}$-ATPase of cardiac sarcoplasmic reticulum are critical for functional association with phospholamban. $J$. Biol. Chem., 269: 22929-22932.

59. Palmer, C.J., Scott, B.T., and Jones, L.R. 1991. Purification and complete sequence determination of the major plasma membrane substrate for cAMP-dependent protein kinase and protein kinase C in myocardium. J. Biol. Chem., 266: 1112611130.

60. Morrison, B.W. and Leder, P. 1994. neu and ras initiate murine mammary tumors that share genetic markers generally absent in c-myc and int-2-initiated tumors. Oncogene, 9: 34173426.

61. Morrison, B.W., Moorman, J.R., Kowdley, G.C., Kobayashi, Y.M., Jones, L.R., and Leder, P. 1995. Mat-8, a novel phospholemman-like protein expressed in human breast tumors, induces a chloride conductance in Xenopus oocytes. $J$. Biol. Chem., 270: 2176-2182.

62. Attali, B., Latter, H., Rachamim, N., and Garty, H. 1995. A corticosteroid-induced gene expressing an "IsK-like" $\mathrm{K}^{+}$ channel activity in Xenopus oocytes. Proc. Natl. Acad. Sci. USA, 92: 6092-6096.

63. Moorman, J.R., Palmer, C.J., John, J.E.III., Durieux, M.E., and JoNES, L.R. 1992. Phospholemman expression induces a hyperpolarization-activated chloride current in Xenopus oocytes. J. Biol. Chem., 267: 14551-14554.

64. Lorentzon, P., Hersey, S.J., Wallmark, B., and Sachs, G. 1989. Ion permeability and pump regulation. In Bicarbonate, chloride, and proton transport systems. (Durham, J.H., Nardy, M.A. eds.) Ann. N.Y. Acad. Sci., 574: 134-144.

65. Forte, J.G., Hanzel, D.K., Urushidani, T., and Wolosin, J.M. 1989. Pumps and pathways for gastric $\mathrm{HCl}$ secretion. In Bicarbonate, chloride, and proton transport systems. (Durham, J.H., Hardy, M.A. eds.) Ann. N.Y. Acad. Sci., 574: $145-158$.

66. CAPLAN, M.J. 1997. Ion pumps in epithelial cells: sorting, stabilization, and polarity. Am. J. Physiol., 272: G1304-1313.

67. Lemas, M.V., Yu, H.-Y., Takeyasu, K., Kone, B., and Fambrough, D.M. 1994. Assembly of Na,K-ATPase $\alpha$-subunit isoforms with $\mathrm{Na}, \mathrm{K}$-ATPase $\beta$-subunit isoforms and $\mathrm{H}, \mathrm{K}$ ATPase $\beta$-subunit. J. Biol. Chem., 269: 18651-18655.

68. Maeda, M., IshizaKi, J., and FutaI, M. 1988. cDNA cloning and sequence determination of pig gastric $\left(\mathrm{H}^{+}+\mathrm{K}^{+}\right)$-ATPase. Biochem. Biophys. Res. Commun., 157: 203-209.

69. Togawa, K., Kaya, S., Shimada, A., Imagawa, T., Mardh, S., Corbin, J., KikKawa, U., and Taniguchi, K. 1996. Ser27, Tyr-10 and Tyr-7 in the $\alpha$-chain of pig stomach $\mathrm{H}^{+}, \mathrm{K}^{+}$ATPase as $\mathrm{Ca}^{2+}$-dependent phosphorylatable sites by intrinsic 
and extrinsic protein kinases. Biochem. Biophys. Res. Commun., 227: 810-815.

70. Burgener-Kairuz, P., Horisberger, J.-D., Geering, K., and Rossier, B.C. 1991. Functional expression of N-terminal truncated $\alpha$-subunits of $\mathrm{Na}, \mathrm{K}$-ATPase in Xenopus laevis oocytes. FEBS Lett., 290: 83-86.

71. Chow, D.C. and Forte, J.G. 1995. Functional significance of the $\beta$-subunit for heterodimeric P-type ATPases. J. Exp. Biol., 198: $1-17$.

72. Calhoun, B.C. and Goldenring, J.R. 1997. Two Rab proteins, vesicle-associated membrane protein 2 (VAMP-2) and secretory carrier membrane proteins (SCAMPs), are present on immunoisolated parietal cell tubulovesicles. Biochem. J., 325: 559-564.

73. Courtois-Coutry, N., Roush, D., Rajendran, V., McCarthy, J.B., Geibel, J., Kashgarian, M., and Caplan, M.J. 1997. A tyrosine-based signal targets H/K-ATPase to a regulated compartment and is required for the cessation of gastric acid secretion. Cell, 90: 501-510.

74. Takahashi, E., Hori, T., O'Connell, P., Leppert, M., and WhITE, R. 1990. R-banding and nonisotopic in situ hybridization: precise localization of the human type II collagen gene (COL2A1). Hum. Genet., 86: 14-16.
75. Takahashi, E., Yamauchi, M., Tsuji, H., Hitomi, A., Meuth, M., and HorI, T. 1991. Chromosomal mapping of the human cytidine- 5 '-triphosphate (CTPS) gene to band $1 \mathrm{p}_{34.1}-\mathrm{p}_{34.3}$ by fluorescence in situ hybridization. Hum. Genet., 88: 119-121.

76. LiChTER, P., LedbetTer, S.A., LedbetTer, D.H., and WARD, D.C. 1990. Fluorescence in situ hybridization with Alu and L1 polymerase reaction probes for rapid characterization of human chromosome in hybrid cell line. Proc. Natl. Acad. Sci. USA, 87: 6634-6638.

77. Chen, L.S., Lo, C.F., Numann, R., and Cuddy, M. 1997. Characterization of the human and rat phospholemman (PLM) cDNAs and localization of the human PLM gene to chromosome 19q13.1. Genomics, 41: 435-443.

78. Sambrook, J., Fritsch, E.F., and Maniatis, T. 1989. Molecular Cloning: A Laboratory Manual. Cold Spring Harbor Laboratory, Cold Spring Harbor, N.Y. 2nd Ed.

(Received for publication, June 28, 1998

and in revised form, October 8,1998 ) 